\title{
The Cricket (Gryllus assimilis) as an Alternative Food Versus Commercial Concentrate for Tilapia (Oreochromis sp.) in the Nursery Stage
}

\author{
Alejandrino Oseguera Alfaro ${ }^{1}$, Wilfredo Lanza Núñez ${ }^{1}$, Jhunior Marcia ${ }^{1} \&$ Ismael Montero Fernández ${ }^{2}$ \\ ${ }^{1}$ National University of Agriculture, Catacamas, Olancho, Honduras \\ ${ }^{2}$ Postgraduate Program in Biodiversity and Biotecnology, Paricarana Campus, Boa Vista, RR, Brazil \\ Correspondence: Alejandrino Oseguera Alfaro, National University of Agriculture, Catacamas, Olancho, \\ Honduras. E-mail: carsanchezok1990@gmail.com
}

\begin{tabular}{|c|c|c|}
\hline Received: December 23, 2018 & Accepted: March 31, 2019 & Online Published: May 15, 2019 \\
\hline doi:10.5539/jas.v11n6p97 & RL: https://doi.org/10.553 & $\ln 6 p 97$ \\
\hline
\end{tabular}

\begin{abstract}
In this paper, a 32\% commercial diet of protein for tilapia fingerlings (Oreochromis sp.) commonly used in fish farms in the country and cricket meal in a mixture with $32 \%$ corn flour as a protein was compared alternative food The breeding, raising and fattening unit of crickets (Gryllus assimilis) was implemented for its subsequent sacrifice and transformation into flour and used as a source of protein in the diet, these gained a weight of $0.70 \mathrm{~g}$. To accommodate the fry, plastic tanks with a capacity of $1 \mathrm{~m}^{3}$ were used, the water was sucked by means of an electric pump; with permanent aeration where 15 individuals of red tilapia per $\mathrm{m}^{3}$ were planted with an average weight of $5 \mathrm{~g}$ which reached an average weight/fish/day of $26 \mathrm{~g}$, a growth/fish/day of $0.86 \mathrm{~g}$, the total biomass was $340 \mathrm{~g}$, and a feed conversion factor (FCA) of 1.16. According to the Student's T analysis and a comparison of means, no differences were found, with a correlation of $83.1 \%$ between the food supplied and the increase in weight, the water parameters were found at an optimum level. The protein percentage of cricket flour ranges between $15 \%$ and $80 \%$ depending on the geographical area, those that were used in the local ration have $58.16 \%$ of crude protein and 9.32 of protein nitrogen, the two rations in comparison had a protein content of $32 \%$.
\end{abstract}

Keywords: protein, food, cricket flour, sustainable development

\section{Introduction}

Currently, the aim is to seek sustainability in long-term animal production, looking for alternative ingredients to conventional ones, since over time, the cost of production has increased by using other food sources rich in proteins such as soybean meal, wheat or other fish (Khan et al., 2016). The creation of insects is an alternative as a source of nutrients for animal feed, since according to Van Huis et al. (2013) is a way to increase the protein source in human and animal nutrition, being an increasingly booming research area to benefit the aquaculture industry (Hardy, 2010). In terms of the nutritional composition of insects, it depends on factors such as the state of development, its habitat and diet, but in terms of nutritional terms, it is a source of nutrients with a high protein content compared to beef or fish, as well as source of fatty acids compared to fish, and can be used as a source of infant supplements in children with malnutrition, as well as rich in micronutrients such as copper, iron, magnesium, manganese, phosphorus, selenium and zinc (Belluco et al., 2013).

According with (Abraves, 2013), hunger will be one of the problems that humanity will face in the future, being that, according to the FAO between the year 2000-2030, the world will have to increase the per capita production of meat by $20 \%$, estimating that in the year 2030, bird production should grow by around $40.4 \%$, bovine $12.70 \%$, fish by $19 \%$ and pig by $20 \%$, high percentages at an accelerated rate of growth.

One of the advantages of using insects for protein production is that insects can convert $2 \mathrm{~kg}$ of food into $1 \mathrm{~kg}$ of body mass, compared to cattle that need $8 \mathrm{~kg}$ of food to produce $1 \mathrm{~kg}$ of live weight gain, in addition to producing a smaller amount of greenhouse gases than conventional animals (Yen, 2014).

Tilapia (Oreochromis sp.) is well accepted in the market of Latin American countries, especially in Mexico, Ecuador and Colombia (Avnimelech, 2007) standing out for its favorable characteristics such as rusticity, sexual precocity and tolerance to different environmental conditions (El-Sayed, 2006). The cultivation of tilapia in 
Honduras, is mainly developed in coastal areas of Honduras, there are 1589 producers that generate 19,000 direct jobs and 50,000 indirect, with an annual production of 29 thousand tons currently in an area of 82,512 hectares, being the largest exporting country of Tilapia for the Europe, Asia and united state who is the world's largest consumer of fresh tilapia (Toledo-Pérez \& García-Capota, 2000).

The objective of this work is to know the growth of tilapia fingerlings (Oreochromis sp.) in controlled environment feeding on cricket meal (Gryllus assimilis) as an alternative food compared to the growth of commercial rations elaborated for the culture of pond fish and commonly used by the local fish farmer.

\section{Material and Methods}

\subsection{Local}

The work was developed in the National University of Agriculture, department of Olancho (Honduras), located 6 $\mathrm{km}$ southeast of the city of Catacamas, developing in two stages, the first stage being to create and reproduce crickets and the second stage in the fish farming section where the productivity indicators and the environmental conditions of water quality were monitored in the form of shelter for the fingerlings of tilapia.

\subsection{Reproduction and Breeding of Crickets (Gryllus assimilis)}

In the first place, the crickets were collected in the grounds of the National University of Agriculture, and later identified in the entomology laboratory of the aforementioned institution, conditioned in plastic boxes of $37.5 \mathrm{~L}$ in a ratio of 30:3, that is to say thirty females for three males with water and foods such as fruits, concentrate and concentrated vegetables.

Fifty breeders were selected (those who were in stable physical condition and those who had reached sexual maturity in 40 days), leaving the crickets for four days to fecundate the females. As an egg laying material, 250 $\mathrm{mL}$ disposable cans were used, which were modified with holes in the contour to allow oxygenation and filled with coconut substrate for oviposition of eggs, with the coconut substrate previously sterilized, followed by Isolation of the females for two days in individual cages, being counted between 800-1000 eggs per posture per female.

At the birth of the micro-crickets, they were collected and moved immediately to maintenance boxes of $37.5 \mathrm{~L}$ and were conditioned with $400 \mathrm{~g}$ of food wheat bran, providing water daily by sprinkling on the walls of the box thus preventing waterlogging, bottom of the box, carrying this stage a period of 20 days.

Subsequently, the 30-day-old micro-crickets were transferred to $37.5 \mathrm{~L}$ fattening boxes previously disinfected and conditioned, creating ideal conditions for the correct development of the cricket. In each box, a weight of $54.48 \mathrm{~g}$ of cricket was installed, with an average weight of each animal of $0.01 \mathrm{~g}$, which is equivalent to 5448 cricket. Those boxes remained for 70 days with an average temperature of $26{ }^{\circ} \mathrm{C}$ and a humidity of $66 \%$.

\subsection{Process of Cricket Flour Preparation (Gryllus assimilis)}

Once the growth was completed for 70 days, the crickets were sacrificed by exposure to low temperatures at $0{ }^{\circ} \mathrm{C}$, causing a thermal shock and in this way their metabolism was reduced and induced a state of lethal hypothermia. Later, the crickets were introduced in boiling water at $80{ }^{\circ} \mathrm{C}$ for 2 minutes to soften the exoskeletons and reduce microbial growth.

Subsequently, the crickets were placed in an oven for $50{ }^{\circ} \mathrm{C}$ for 16 hours to be dried and then centrifuged for particle homogenization. The sample was sent to the quality control laboratory S. José de Tegucigalpa (Honduras), where it was evaluated by chemical analysis to determine its quality as an alternative food, considering the protein content as the main parameter.

\subsection{Preparation of Lifting Units of Red Tilapia Fingerlings (Oreochromis sp.)}

Once the number of crickets corresponding to the rest of the evaluation days was obtained, the fattening unit was assembled, installing two bins with water storage capacity of $1 \mathrm{~m}^{3}$ in which the re-seeding of tilapia was done in the nursery phase, whose unit has a water exchange system, permanent aeration system to ensure adequate levels of oxygen, a bird protection system was used to prevent losses caused by predators and once the water quality was verified, it was acceptable. He made sowing of fingerlings with density of 15 individuals per bin, being evaluated during 60 days with an initial weight of 5 grams.

\subsection{Feeding the Red Tilapia Fingerlings (Oreochromis sp.)}

The feeding was provided in a single daily ration, starting with the amount of 8 grams of food (RC) commercial ration and (RL) local ration cricket meal and cornmeal both at $32 \%$ protein for a period of 15 days, then a decrease to 7 grams of food for a period of 15 days and from day 31 the food was supplied as required by the fry 
of each tank, which were $16 \mathrm{~g}$ from day 31 to day 45 and $30 \mathrm{~g}$ from day 46 to day 60 , the feeding was done taking advantage of the hours with greater solar radiation, supplying the same amount for both groups in the form of a mass inside a feeder to avoid the waste of food.

The elaboration of the mixture of the local ration was determined through a mass balance exercise for two ingredients which are complemented to obtain the desired level of a nutrient, the cricket meal used in the local ration contains $58.16 \%$ protein raw and $9.32 \%$ protein nitrogen.

\subsection{Variables to Be Evaluated in Red Tilapia Fingerlings (Oreochromis sp.)}

The parameters evaluated were: average weight (grams), growth in day (grams), total biomass and food conversion factor according with Santos (1978) and Swingle (1961).

\subsubsection{Average Weight ( $\mathrm{g} /$ fish)}

Which is obtained by dividing the total weight of the fish by the number of individuals captured:

$$
\mathrm{Xp}=\frac{\text { Weight of fish }}{\mathrm{Nm}}
$$

where, $\mathrm{Xp}=$ Average weight/fish; $\mathrm{Nm}=$ Number of total fish.

\subsubsection{Growth in Day (g/fish/day)}

Which is determined by subtracting the average of the fish from the sample of the average of the fish at the sowing between the time of the sowing and sampling:

$$
\mathrm{CPD}=\frac{\mathrm{Xpm}-\mathrm{Xps}}{\mathrm{Tsm}}
$$

where, $\mathrm{CPD}=$ Growth in $\mathrm{gr} / \mathrm{fish} / \mathrm{day} ; \mathrm{Xpm}=$ Average/fish to the sample; $\mathrm{Xps}=$ Average/fish at planting $; \mathrm{Tsm}=$ Average/fish at planting.

\subsubsection{Total Biomass}

It is calculated by weighing the total number of individuals captured from sowing to partial or final sampling by multiplying the fish average to the sample by the number of fish sown minus mortality:

$$
\text { Biomass }=\mathrm{Xpm}(\mathrm{Ns}-\mathrm{M})
$$

where, $\mathrm{Ns}=$ Number of fish planted; $\mathrm{M}=$ Mortality; $\mathrm{Xpm}=$ Average/fish to the sample.

\subsubsection{Food Conversion Factor}

$$
\text { FCA }=\frac{\text { Supplied food }}{\text { Gained weight }}
$$

where, FCA $=$ Conversion factor.

\subsection{Water Quality Parameters}

They were measured as water quality parameters (temperature, $\mathrm{pH}$, turbidity and dissolved oxygen). The temperature of the water was directly taken with a thermometer, making different shots and taking an average (between 07:00 AM and 06:00 PM), pH measurements of the water were also taken by taking a daily sample of both tanks by 60 days, the water samples for the dissolved oxygen analysis were taken once a week in both tanks, the measurement of the turbidity was once a week using the water exchanges were made in 3-day intervals during 60 days (Macedo, 2008).

\subsection{Statistic Analysis}

The results were analyzed from Student's T tests in Excel and the IBM program, SPSS, version 22.0, using statisticians, descriptive statistics, normality tests, homogeneity of variance and correlation tests.

\section{Results and Discussion}

\subsection{Growth Indicators of Red Tilapia (Oreochromis sp.)}

Table 1 shows the different growth indicators of red tilapia in plastic tanks with a capacity of $1 \mathrm{~m}^{3}$ for 60 days in the fish section of the National University of Agriculture in Catacamas Olancho, Honduras. 
Table 1. Indicators of red tilapia growth productivity

\begin{tabular}{lllllll}
\hline Ration & Protein & Biomass at planting & Final Biomass & FCF & Survival & Average growth/day \\
\hline Local & $32 \%$ & $0.17 \mathrm{lb}$ & $0.654 \mathrm{lb}$ & 1.31 & $87 \%$ & 0.86 \\
Commercial & $32 \%$ & $0.17 \mathrm{lb}$ & $0.740 \mathrm{lb}$ & 1.16 & $87 \%$ & \\
\hline
\end{tabular}

Note. $\mathrm{lb}=$ pound $; \mathrm{FCF}=$ food conversión factors.

Four weight samples were taken for one during 60 days in the raising of red tilapia fingerlings (Oreochromis sp.) in the fish section of the National Agricultural University. Table 1 summarizes the amount of biomass at sowing and final, as well as the feed conversion factors (FCF), survival and growth per day in fish, demonstrating that there is no statistically significant difference between the test factors in relation to the levels of the type of feeding with the commercial concentrate and the mixture of cricket flour and corn (Figure 1).

This could be due to the amount of nutrients contained in the cricket meal, since it has all the necessary nutrients for the good biological development of the fish, where the tilapia takes advantage of $75 \%$ of the protein contained in the crickets, these results affirm the substitution of fishmeal for cricket meal as a source of protein in the diet of fish (Ogunji et al., 2008; Alegbeleye et al., 2012; Emehinaiye, 2012; Jabir et al., 2012).

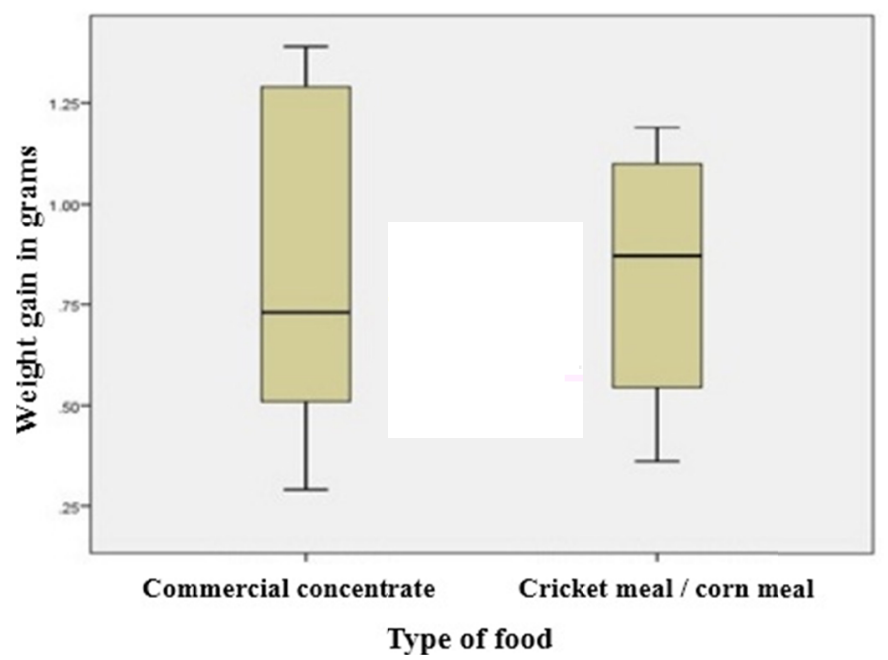

Figure 1. Multiple comparison diagram

There is no significant difference between the rations supplied, but if there is a high correlation between the ration type and the weight gain, both values are within the ranges of the multiple comparison box and mustache, which indicates that the higher Food consumption will be greater weight gain and height.

\subsection{Influence of Biomass}

The analysis made from the data of total amount of biomass in a period of 60 days between the two rations evaluated in the two groups of individuals results in no significant difference observed $P(T \leq t)$ two tails 0.131038 . The difference is closely related to the type of food supplied and that plays a very important role in the raising of commercial fish such as tilapia (Figure 2). 


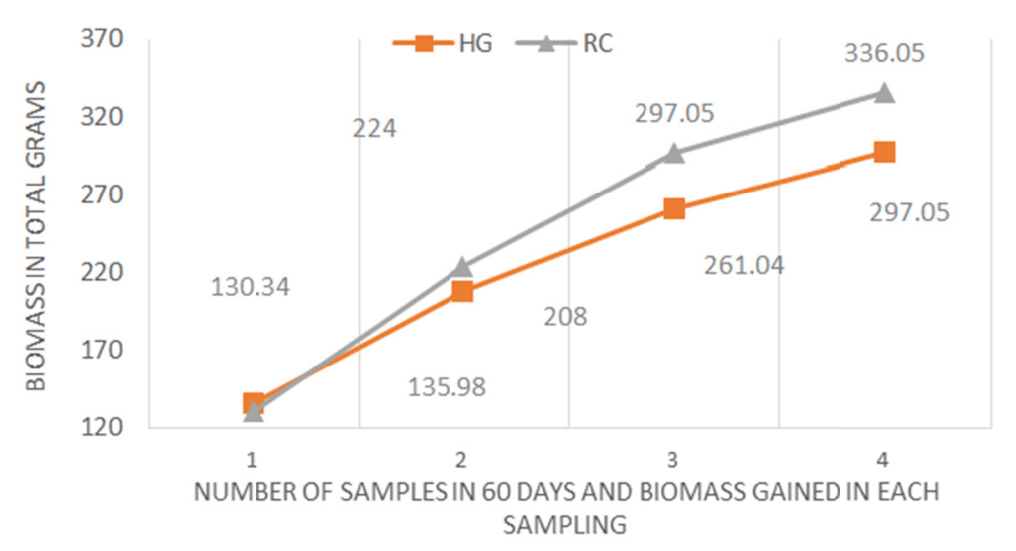

Figure 2. Total differences in biomass gained by both groups of fingerlings (Oreochromis sp.), among the rations evaluated in plastic tanks with a capacity of $1 \mathrm{~m}^{3}$ for raising tilapia fingerlings (Oreochromis sp.) for 60 days in the fish section of the National Agriculture University in Catacamas Olancho, Honduras, CA

Insects are part of the natural diet of many animals including freshwater fish, also have similarities in their body condition with crustaceans since both have the same phylum (arthropoda), these are widely consumed by fish from the sea and they play an important role in human nutrition, the entomophagy laboratory of Wageningen University conducted an inventory of 2163 species of edible insects and crickets represent $13 \%$ of world consumption (Van Huis, 2013).

These can influence some characteristics of the fish such as vigor and coloring in the scales, skin and eyes by high content of essential acids, in the not too distant future it will serve as a substitute for fishmeal and meat and bone meal used as raw material for the elaboration of feed on an industrial scale in the feeding of species of aquaculture exploitation, also by the low amount of resources that are needed for the fattening of the shackles and the low quantity of pollutants like methane gas $\mathrm{CH}_{4}$ fired by the crickets to the atmosphere.

\subsection{Physicochemical Properties of Water}

In Table 2, the physicochemical parameters in the water of raising red tilapia (Oreochromis sp.) Fingerlings in plastic tanks with a capacity of $1 \mathrm{~m}^{3}$ for 60 days for both the local ration and the commercial ration are collected.

Tablet 2. Physicochemical parameters in the water of the red tilapia (Oreochromis sp.)

\begin{tabular}{lllll}
\hline & Temperature $\left({ }^{\circ} \mathrm{C}\right)$ & Dissolved oxygen $\left(\mathrm{mg} \mathrm{L}^{-1}\right)$ & $\mathrm{pH}$ & Turbidity (UNT) \\
\hline Local portion & $24-27$ & $8-10$ & 7.5 & $20-30$ \\
Commercial ration & $24-28$ & $8-12$ & 7.6 & $20-30$ \\
\hline
\end{tabular}

When analyzing the temperature data recorded in the tanks in morning and evening hours, these ranges have no influence on the biological behavior of the tilapia fingerlings (Oreochromis sp.), they did not cause any type of biological or physical alteration since this range is Near the optimum temperature range for tilapia culture that is between $28{ }^{\circ} \mathrm{C}$ and 32 , they decrease their metabolism when the temperature drops to $15^{\circ} \mathrm{C}$ and they do not survive at less than $12{ }^{\circ} \mathrm{C}$.

The $\mathrm{pH}$ is important in the quality of water, since it controls both the balance of the chemical reactions that develop in the water and the biological activity that generally develops between values of $\mathrm{pH}$ 6-8 (De Souza, 2001), being the values of $\mathrm{pH}$ of this work in a range of 7.5-7.6, this variation does not have any negative incidence in the biological development of the fish, since it is in the adequate range for the culture of tilapia, being that these prefer a neutral or slightly alkaline $\mathrm{pH}$.

The importance of turbidity in water quality must be highlighted, since in human drinking water it protects human organisms from contamination and reflects the amount of materials, colors, minerals and organic matter present in the water, being able to be an indicator of water pollution (Espigares \& Fernández-Crehuet, 1999). In this work, the parameters measured are in accordance with the established limits (WHO, 1995). In relation to the analyzed data, the level of turbidity contained in the water does not represent a risk for the good development of 
the fry, does not affect the quality of the water, nor does it diminish the nutritional and commercial value of the meat of the fish since it was found in a range of 20-30 UNT.

Dissolved oxygen (DO) is one of the most important water quality parameters, since it indicates the contamination of the same, being that the waters that present low values of DO, are caused by the presence of organic matter or material oxidized (Posada et al., 2013). The concentration of dissolved oxygen contained in the water samples determined that the levels found are adequate for the development of the fry. Tilapia supports levels of $1 \mathrm{mg} \mathrm{L}^{-1}$ of oxygen, in the absence of light of 2 to $3 \mathrm{mg} \mathrm{L}^{-1}$, but the optimal level is of 8 to $12 \mathrm{mg} \mathrm{L}^{-1}$, they develop in a good way in the latter, they were not found critical levels of dissolved oxygen, these samples were taken at different times of the day and with different conditions of the time.

\section{Conclusions}

According to the growth comparison between the supply of cricket meal with corn flour and commercial ration to the tilapia fingerlings, it was determined that there are no significant growth differences.

The physicochemical parameters of the water did not affect the development of the individuals, nor did they cause physiological alterations that could directly or indirectly affect the fry because all the parameters are within an acceptable range.

The local ration consisting of cricket flour (Gryllus assimilis) and nixtamalized corn flour, can be a viable alternative for its high content of nutrients mainly protein, fatty acids and fiber, if the fish farmer has his own source of flour supply crickets The physicochemical parameters of the water did not affect the development of the individuals, nor did they cause physiological alterations that could directly or indirectly affect the fry because all the parameters are within an acceptable range

It was determined that the survival rate was high, in both groups of individuals, which indicates that they developed in an adequate environment and took advantage of the food supplied.

\section{References}

Abraves. (2013). Um diferencial na produção de proteina Carne suína "made in Brasil" tem tecnologia e isso significa a melhor qualidade e o menor custo da produção. Congresso Abraves, Florianópolis-SC.

Avnimelech, Y. (2007). Feeding with microbial flocs by tilapia in minimal discharge bio-flocs technology ponds. Aquaculture, 264, 140-147. https://doi.org/10.1016/j.aquaculture.2006.11.025

Alegbeleye, W. O., Obasa, S. O., Olude, O. O., Otubu, K., \& Jimoh, W. (2012). Preliminary evaluation of the nutritive value of the variegated grasshopper (Zonocerus variegatus L.) for African catfish Clarias gariepinus (Burchell. 1822) fingerlings. Aquaculture Research, 43, 412-420. https://doi.org/10.1111/j.13652109.2011.02844.x

Belluco, S., Locasso, C., Maggioletti, M., Alonzi, C., Paoletti, M., \& Ricci, A. (2013). Edible insects in a food safety and nutritional perspective: A critical review. Comprehensive Reviews in Food Science and Food Safety, 12, 296-313. https://doi.org/10.1111/1541-4337.12014

De Souza, E. R. (2001). Noções sobre qualidade da água. Instituto Superior Técnico. Departamento de Engenharia Civil e Arquitectura. Lisboa.

El-Sayed, A. F. M., \& Kawanna, M. (2008). Effects of dietary protein and energy levels on spawning performance of Nile tilapia (Oreochromis niloticus) broodstock in a recycling system. Aquaculture, 280(1), 179-184. https://doi.org/10.1016/j. aquaculture.2008.04.030

Emehinaiye, P. A. (2012). Growth performance of Oreochromis niloticus fingerlings fed with varying levels of migratory locust (Locusta migratoria) meal (Bachelor of Aquaculture and Fisheries Management, Federal University of Agriculture, Abeokuta, Ogun State).

Espigares, G. M., \& Fernández-Crehuet, M. (1999). Calidad del agua para consumo público: Caracteres fisico-químicos en el estudio sanitario del agua (pp. 85-114). Granada.

Hardy, R. W. (2010). Utilization of plant proteins in fish diets: Effects of global demand and supplies of fishmeal. Aquas Res, 41, 770-776. https://doi.org/10.1111/j.1365-2109.2009.02349.x

Khan, S., Naz, S., Sultan, A., Alhidary, I. A., Abdelrahman, M. M., Khan, R. U., Khan, N. A., ... Ahmad, S. (2016). Worm meal: A potential source of alternative protein in poultry feed. World's Poultry Science Journal, 72(1), 93-102. https://doi.org/10.1017/S0043933915002627

Jabir, M. D. A. R. J., Razak, S. A., \& Vikineswary, S. (2012). Nutritive potential and utilization of super worm 
(Zophobas morio) meal in the diet of Nile tilapia (Oreochromis niloticus) juvenile. African Journal of Biotechnology, 11, 6592- 6598. https://doi.org/10.5897/AJB11.1084

Macedo, J. A. de B. (2005). Métodos laboratoriais de análises físico-químicas e microbiológicas (p. 450). Consejo Regional de Química-Minas Gerais.

Ogunji, J., Pagel, T., Schulz, C., \& Kloas, W. (2009). Apparent digestibility coefficient of housefly maggot meal (magmeal) for Nile tilapia (Oreochromis niloticus L.) and carp (Cyprinus carpio). Asian Fisheries Science, 22, 1095-1105.

Posada, E., Mojica, D., Pino, N., Bustamante, C., \& Pineda, A. M. (2013). Establishment of environmental quality índices of rivers according to the behavior of disolved oxygen and temperature. Applied to the Medellin River, in the Valley of Aburra in Colombia. Dyna, 80, 181, 192-200.

Santos, E. P. (1978). Dinâmica de populações aplicada à pesca e piscicultura (p. 129). São Paulo, Hucitee.

Swingle, H. S. (1961). Relationship of $\mathrm{pH}$ of pond wáter to their suitability for fish culture. Fisheries, 10(1), $72-75$.

Toledo-Pérez, S. J., \& García-Capote, M. C. (2000). Nutición y alimentación de tilapia cultivada en América Latina y el Caribe. Avances en Nutrición Acuícola, IV Memorias del IV Simposium Internacional de Nutrición Acuícola, La Paz, B.C.S., México.

Van Huis, A. (2013). Potential of insects as food and feed in assuring food security. Annual Review of Entomology, 58, 563-583. https://doi.org/10.1146/annurev-ento-120811-153704

Yen, A. L. (2014). Foreword: Why a Journal of insects as food and feed? Journal of Insects as Food and Feed, 1(1), 1-2. https://doi.org/10.3920/JIFF2015.x001 


\section{Appendix A}

Images of the process developed in this work
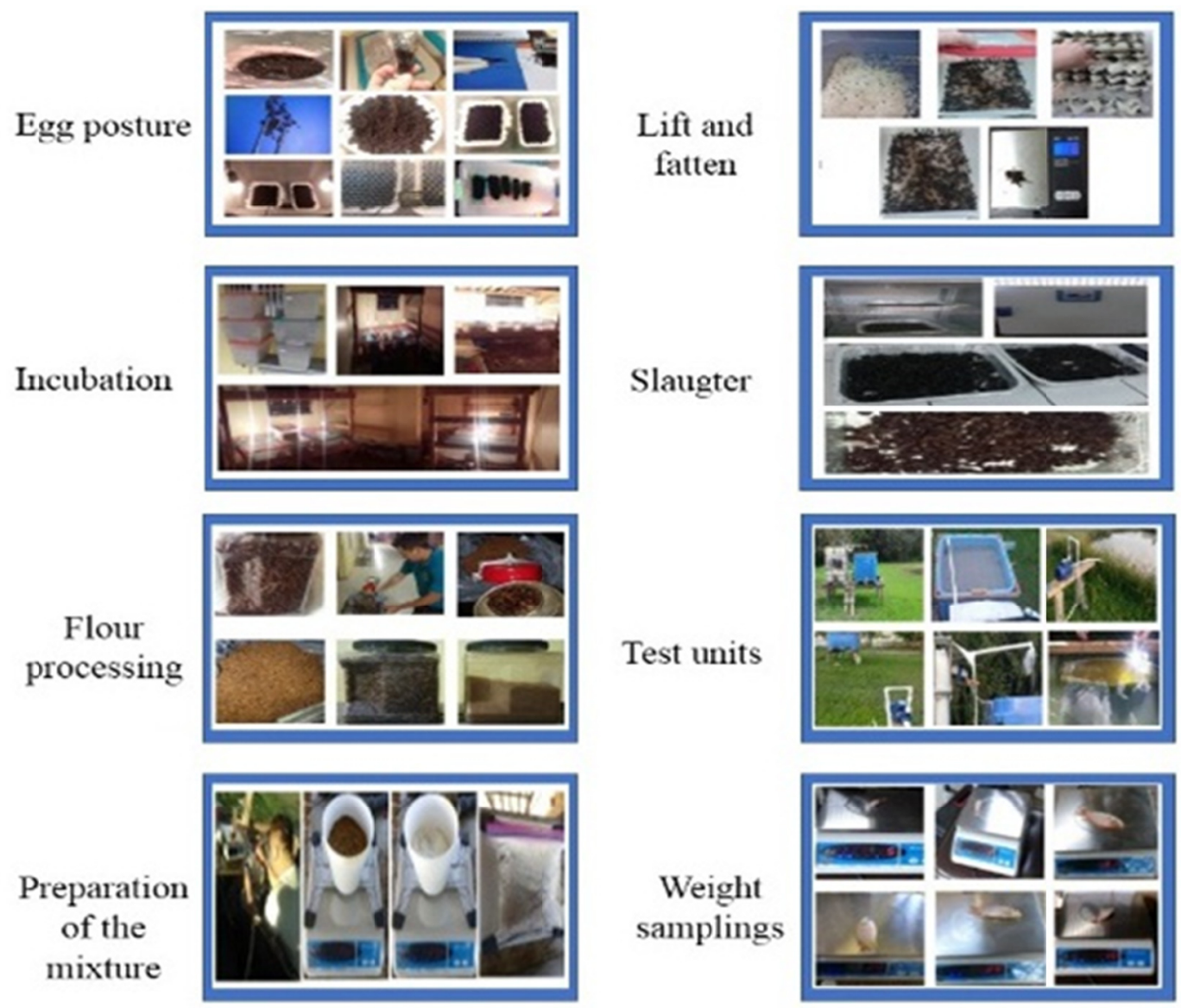

\section{Copyrights}

Copyright for this article is retained by the author(s), with first publication rights granted to the journal.

This is an open-access article distributed under the terms and conditions of the Creative Commons Attribution license (http://creativecommons.org/licenses/by/4.0/). 